\title{
Nematode assemblages from the Kandalaksha Depression (White Sea, 251-288 m water depth)
}

\author{
Dmitry M. Miljutin • Maria A. Miljutina • \\ Alexei V. Tchesunov $\cdot$ Vadim O. Mokievsky
}

Received: 29 May 2013/Revised: 26 September 2013/Accepted: 8 October 2013/Published online: 1 November 2013

(C) Springer-Verlag Berlin Heidelberg and AWI 2013

\begin{abstract}
The shallow-water nematodes of the White Sea are relatively well studied; however, information on the nematode fauna inhabiting the deepest part of this sea is very scarce. The composition of the nematode assemblages (at species and genus level) was studied in samples collected during four sampling occasions in the deepest part of the Kandalaksha Depression (the White Sea) in July 1998, October 1998, May 1999, and November 1999. Samples were collected from a depth of 251-288 m with the aid of a multicorer. In total, 59 nematode morphotypes belonging to 37 genera and 18 families were distinguished. The genera Sabatieria and Filipjeva dominated at all stations, followed by Aponema, Desmoscolex, and Quadricoma. The composition of the dominant genera can be considered typical for this depth range in temperate and Arctic waters, although Filipjeva and Aponema were among the dominant genera for the first time. The most abundant species were Sabatieria ornata, Aponema bathyalis, and Filipjeva filipjevi. In general, diversity of the nematode assemblages was lower than in the temperate and Arctic continental shelf and slope with reduced evenness and species richness.
\end{abstract}

Communicated by H.-D. Franke.

D. M. Miljutin $(\bowtie) \cdot$ M. A. Miljutina

Senckenberg am Meer, Deutsches Zentrum für Marine

Biodiversitätsforschung, Südstrand 44, 26382 Wilhelmshaven, Germany

e-mail: dmiljutin@senckenberg.de

\section{A. V. Tchesunov}

Department of Invertebrate Zoology, Faculty of Biology,

Moscow State University, 119991 Moscow, Russia

V. O. Mokievsky

P.P.Shirshov Institute of Oceanology, Russian Academy of

Science, Nakhimov Prospekt 36, 117218 Moscow, Russia
The evenness of nematode assemblages and other diversity indices decreased with increasing sediment depth. Based on the valid species and genera recorded, the nematode fauna of the Kandalaksha Depression showed a higher resemblance to that found in the shallow waters of Kandalaksha Bay.

Keywords Abundance - Community · Diversity · Filipjeva filipjevi · Meiobenthos · Pseudo-bathyal · Sabatieria ornata

\section{Introduction}

The White Sea is a small marginal shelf sea separated from the Arctic Ocean by the shallow and narrow Gorlo Strait (Filatov et al. 2005; Berger et al. 2001), resulting in relatively unusual conditions in its deepest regions (small depressions with a maximum depth of $343 \mathrm{~m}$ ): the deep water is very cold (about $-1.5^{\circ} \mathrm{C}$ ) and not fully saline (29.5-30.0 \%o) (Loeng 1991; Berger and Naumov 2000). This type of marginal shelf depression, detached from the main oceanic water body by shallow sills, is called the "pseudo-bathyal" (Andriashev 1977).

The macrobenthic fauna has been well studied in this sea (for the most comprehensive and up-to-date catalog of the White Sea biota, see Tchesunov et al. (2008)). However, information on the diversity and distribution of meiobenthic organisms is rather scarce, and mostly concerns the tidal and subtidal zones.

The first nematode species recorded from the White Sea were described by Filipjev (1927), although more regular studies of the White Sea nematofauna did not start until the 1970s (Frolov 1972; Galtsova 1976, Aminova and Galtzova 1978; Galtsova 1982; Belogurov and Galtzova 1983; 
Tchesunov and Krasnova 1985; Mokievsky 1990). In the tidal zone, studies on nematode assemblages and species distribution (Galtsova 1991), vertical distribution of nematode species (Galtsova 1982), and seasonal dynamics of nematode species and assemblages (Galtsova and Aminova 1978; Mokievsky 1990; Krasnova 2007) have been undertaken.

The nematofauna from the upper subtidal zone of the White Sea has been found to be more diverse than the tidal zone, but has been studied far less: the portion of unknown species among the subtidal nematodes is still much higher that among the tidal. Nematode studies in the upper subtidal have been mainly performed at two Russian biological stations belonging to the Moscow State Universty and the St. Petersburg Zoological Intstitute of the Russian Academy of Science. Most of these studies were taxonomic (see, e.g., Tchesunov and Krasnova 1985; Tchesunov 1987, 1988a, b, 1989, 1990a, b, c, 1993, 1996, 2000a, b; Platonova and Mokievsky 1994; Decraemer and Tchesunov 1996; Okhlopkov 2002; Tchesunov and Miljutina 2002, 2008; Kovalyev and Tchesunov 2005; Tchesunov and Milyutin 2007). In total, 127 nematode species were reported from the tidal and upper subtidal zones near the White Sea Biological Station (Moscow State University) in the Kandalaksha Bay (Tchesunov and Walter 2008).

Nematodes from the lower sublittoral and pseudobathyal of the White Sea have been little studied, and few new species have been described from these depths (Tchesunov 1988a; Tchesunov and Miljutina 2008; Kovalyev and Miljutina 2009). Galtsova and Platonova (1988) and Galtsova (1991) analyzed nematode species distributions from the tidal zone to $300 \mathrm{~m}$ water depth and detected three main nematode assemblages, each inhabiting a specific depth range and sediment type.

In 1998, a cooperative German-Russian scientific program "The investigation of the deep-sea ecosystem of the White Sea" was initiated with support from the International Association for the Promotion of Co-operation with Scientists from the New Independent States of the Former Soviet Union (INTAS) (Rachor 2000). Through this project, significant effort was made to collect qualitative and quantitative data on the deep-sea meiofauna of the Kandalaksha Depression. Four cruises (July 1998, October 1998, May 1999, and November 1999) collected mini-corer samples for meiobenthic studies from a depth of 251-288 m, and initial findings (based on the first cruise) were reported by Mokievsky et al. (2009). Miljutin et al. (2012) used the whole set of data (four cruises) to describe the patterns in density, relative abundance, and size spectrum of the major meiobenthic taxa. The most abundant meiobenthic group was Foraminifera (59\%), followed by Nematoda $(26 \%)$ and
Harpacticoida $(7 \%)$. These relative and absolute abundance values were comparable with those from the same depth interval in Arctic and temperate regions. The densities of foraminiferans and nematodes were higher in Autumn and lower in Summer, reflecting a mass propagation event dependent on the influx of primary production from surface waters. The size range of the meiobenthos in the deepest part of the White Sea was comparable to that of deep-sea meiobenthos, in which the 63-125- $\mu \mathrm{m}$-size class and $125-250-\mu \mathrm{m}$-size class were most dominant.

The aim of the present work was to describe the diversity and composition of nematode assemblages from the above-mentioned deep-sea site of the Kandalaksha Depression, since nematodes were the most abundant meiobenthic Metazoan in the samples.

\section{Materials and methods}

The sediment in the sampling area was a liquid, clayey mud. A more detailed description of the sampling area is given by Miljutin et al. (2012).

Meiobenthos was collected during four cruises of the RV "Kartesh" and the RV "Professor Kuznetsov" (Zoological Institute, Russian Academy of Sciences). Samples were obtained in July and October 1998 and in May and November 1999 (Table 1, Fig. 1). For more detailed information on location of stations, see Miljutin et al. (2012). One station was sampled on each cruise (i.e., four stations in total).

Samples were taken using a mini-corer bearing four plastic corers with an internal diameter of $5.4 \mathrm{~cm}$. In total, nine samples (three deployments, three cores from each deployment) were collected in July 1998; six samples in October 1998 (two deployments, three cores from each deployment); five samples in May 1999 (from three deployments); and three samples (one deployment, three cores) in November 1999. It was not possible to acquire triplicate samples for every deployment at station CBB-23 owing to technical problems.

Meiobenthos was collected from the corers using cutoff syringes with an internal diameter of $2 \mathrm{~cm}$ (one syringe per core). Each syringe was divided into five subsamples representing 1-cm-thick layers from the surface down to $5 \mathrm{~cm}$ sediment depth $(0-1,1-2,2-3,3-4$, and $4-5 \mathrm{~cm})$. All subsamples were fixed a solution of $10 \%$ formalin in seawater.

In the laboratory, subsamples were washed over a $32-\mu \mathrm{m}$ mesh sieve, stained with $1 \%$ rose bengal, and sorted under a stereo microscope using a Bogorov counting chamber. Nematodes were picked out, processed in glycerin using the Seinhorst's method of slow evaporation 
Table 1 Sample details

\begin{tabular}{|c|c|c|c|c|c|c|c|}
\hline Station & Date & Deployment (No.) & Latitude $(\mathrm{N})$ & Longitude (E) & Depth (m) & $\begin{array}{l}\text { Number of cores } \\
\text { taken for nematode } \\
\text { examination }\end{array}$ & $\begin{array}{l}\text { Number of nematodes } \\
\text { examined in every core }\end{array}$ \\
\hline \multirow[t]{3}{*}{ CBB-20 } & 27.07.1998 & 1 & $66^{\circ} 25.99^{\prime}$ & $34^{\circ} 22.47^{\prime}$ & 270 & 3 & $741 ; 324 ; 25$ \\
\hline & & 2 & $66^{\circ} 25.95^{\prime}$ & $34^{\circ} 22.23^{\prime}$ & 270 & 3 & $70 ; 134 ; 102$ \\
\hline & & 3 & $66^{\circ} 26.02^{\prime}$ & $34^{\circ} 21.88^{\prime}$ & 270 & 3 & $71 ; 198 ; 68$ \\
\hline \multirow[t]{2}{*}{ CBB-22 } & 15.10 .1998 & 1 & $66^{\circ} 26.03^{\prime}$ & $34^{\circ} 19.50^{\prime}$ & 288 & 3 & $104 ; 250 ; 46$ \\
\hline & & 2 & $66^{\circ} 24.93^{\prime}$ & $34^{\circ} 19.86^{\prime}$ & 277 & 3 & $300 ; 7 ; 21$ \\
\hline \multirow[t]{3}{*}{ CBB-23 } & 31.05 .1999 & 1 & $66^{\circ} 25.59^{\prime}$ & $34^{\circ} 20.75^{\prime}$ & 251 & 3 & $67 ; 110 ; 37$ \\
\hline & & 2 & $66^{\circ} 25.16^{\prime}$ & $34^{\circ} 24.09^{\prime}$ & 274 & 1 & 108 \\
\hline & & 3 & $66^{\circ} 24.49^{\prime}$ & $34^{\circ} 24.09^{\prime}$ & 270 & 1 & 74 \\
\hline CBB-34 & 24.11.1999 & 1 & $66^{\circ} 25.20^{\prime}$ & $34^{\circ} 22.08^{\prime}$ & 270 & 3 & $102 ; 45 ; 141$ \\
\hline
\end{tabular}

The position of sampling sites, date of sampling, number of replicates (cores) taken for meiobenthic study from every multi-corer deployment, and number of nematode individuals examined in each core

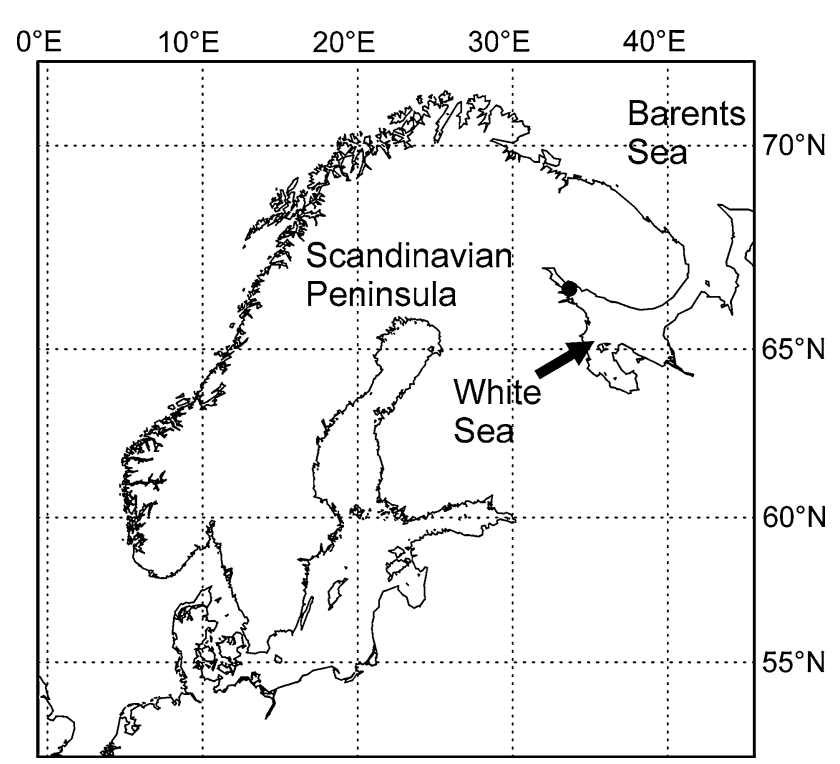

Fig. 1 Map of region and site of sampling (marked with black circle)

(Seinhorst 1959), and mounted on permanent glycerinparaffin slides. The nematodes were then examined under a light microscope. In total, 3,145 nematode individuals were examined (Table 1).

The software packages PAST (Hammer et al. 2001) and PRIMER v6 (Clarke and Gorley 2006) were used for statistical analysis.

Nematode diversity in the uppermost 5 - $\mathrm{cm}$ sediment layer at species and genus level was measured using Margalef's $(d), \log _{2^{-}}$and $\log _{\mathrm{e}}$-based Shannon-Wiener $\left(H^{\prime}\right)$, Hill's $\left(N_{\infty}\right)$, and Pielou's $\left(J^{\prime}\right)$ indices, and richness was also estimated as $E S(51)$ and $E S(100)$ for species level, and $E G(51)$ and $E G(100)$ for genus level (51 and 100 being a standardized number of specimens). For the latter index, only samples containing not less than 51 and 100 individuals, respectively, were analyzed. For the comparison of nematode diversity from different 1 -cm-thick sediment layers, $E S(31)$ for species was calculated (owing to the small sample size), as well as $d, J^{\prime}$, and $H^{\prime}$ indices.

Analysis of similarity (ANOSIM) based on Bray-Curtis similarity distances was used to analyze the multivariate data (square-root-transformed relative abundances of nematode species in each samples). One-way and two-way nested ANOSIM tests were used to compare differences between stations, deployments, and sediment layers. Similarity percentage analysis (SIMPER) based on Bray-Curtis similarity distance was used to assess which taxa were primarily responsible for any observed differences between groups of samples. The significance of differences in the ratio juveniles/adults and diversity indices was tested using two-way ANOVA, Kruskal-Wallis, and Mann-Whitney $U$ tests. The significance of the deviation of the ratio males/ females from 1 was tested by a $\chi^{2}$ test. Two factors were used for the two-way ANOVA: "Year" (1998 and 1999) and "Season" (Summer and Autumn).

The vertical distribution of nematode assemblages was studied for the $0-1-\mathrm{cm}, 1-2-\mathrm{cm}$, and $2-3-\mathrm{cm}$ sediment layers only because of the limited number of specimens in the $3-4-\mathrm{cm}$ and $4-5-\mathrm{cm}$ sediment layers. In order to enlarge the sample volume, and therefore the number of specimens available for analysis, all samples from the same deployment were merged.

The pairwise comparison of the nematode taxa found in the Kandalakscha Depression (presence/absence matrix of valid species and genera) with other nematofaunas described from the White Sea was undertaken using Simpson's resemblance index (Simpson 1960):

$C / N_{\min } \times 100$,

where $C$ is the number of taxa common to both nematofaunas; $N_{\min }$ is the number of taxa in the nematofauna 
Table 2 List of identified taxa and the number of species (morphotypes) determined

\begin{tabular}{|c|c|c|}
\hline Family & Genus & Number of species \\
\hline Aegialoalaimidae & Aegialoalaimus & 2 \\
\hline Anoplostomatidae & Anoplostoma & 1 \\
\hline Camacolaimidae & Camacolaimus & 1 \\
\hline Ceramonematidae & Pselionema & 1 \\
\hline \multirow[t]{5}{*}{ Chromadoridae } & Acantholaimus & 1 \\
\hline & Actinolaimus & 1 \\
\hline & Atrochromadora & 1 \\
\hline & Neochromadora & 1 \\
\hline & Trochamus & 1 \\
\hline \multirow[t]{2}{*}{ Comesomatidae } & Cervonema & 2 \\
\hline & Sabatieria & 2 \\
\hline \multirow[t]{3}{*}{ Desmoscolecidae } & Desmoscolex & 3 \\
\hline & Quadricoma & 1 \\
\hline & Tricoma & 2 \\
\hline \multirow[t]{5}{*}{ Diplopeltidae } & Campylaimus & 3 \\
\hline & Diplopeltula & 2 \\
\hline & Intasia & 2 \\
\hline & Pararaeolaimus & 2 \\
\hline & Southerniella & 1 \\
\hline Fusivermidae & Fusivermis & 2 \\
\hline Leptolaimidae & Leptolaimus & 1 \\
\hline Leptosomatidae & Crenopharynx & 1 \\
\hline Meyliidae & Gerlachius & 1 \\
\hline \multirow[t]{2}{*}{ Microlaimidae } & Aponema & 2 \\
\hline & Microlaimus & 2 \\
\hline \multirow[t]{3}{*}{ Monhysteridae } & Geomonhystera & 1 \\
\hline & Monhystera & 1 \\
\hline & Thalassomonhystera & 1 \\
\hline \multirow[t]{2}{*}{ Oxystominidae } & Halalaimus & 1 \\
\hline & Oxystomina & 1 \\
\hline Siphonolaimidae & Siphonolaimus & 1 \\
\hline Sphaerolaimidae & Sphaerolaimus & 2 \\
\hline \multirow[t]{5}{*}{ Xyalidae } & Amphimonhystera & 2 \\
\hline & Daptonema & 2 \\
\hline & Filipjeva & 3 \\
\hline & Marisalbinema & 2 \\
\hline & Theristus & 1 \\
\hline
\end{tabular}

with the shorter list of taxa. To this aim, a list of tidal and subtidal nematode species found in the area of the White Sea Biological Station (Moscow State University, Russia) in the Kandalaksha Bay (Tchesunov and Walter 2008) was created, as well as lists of tidal nematofauna from other area of the Kandalaksha Bay and nematofaunas from 2, $5-15$, and $18-300 \mathrm{~m}$ depths from the central part of the White Sea (Galtsova 1991).
Table 3 Average density and relative abundance of valid nematode species found in the deepest part of the Kandalaksha Depression (averaged across 4 cruises), with known habitat indicated

\begin{tabular}{|c|c|c|c|}
\hline Species & $\begin{array}{l}\text { Average } \\
\text { density, } \\
\text { ind. } / 10 \mathrm{~cm}^{2}\end{array}$ & $\begin{array}{l}\text { Average } \\
\% \text { in } \\
\text { assemblage }\end{array}$ & $\begin{array}{l}\text { Formerly } \\
\text { known } \\
\text { habitat }\end{array}$ \\
\hline $\begin{array}{l}\text { Aegialoalaimus elegans De Man } \\
1907\end{array}$ & $0.3 \pm 0.2$ & $0.1 \pm 0.0$ & A \\
\hline $\begin{array}{l}\text { Amphimonhystera galea Fadeeva } \\
1984\end{array}$ & $0.4 \pm 0.2$ & $0.2 \pm 0.1$ & $\mathrm{~B}$ \\
\hline $\begin{array}{l}\text { Aponema bathyalis Kovalyev et } \\
\text { Miljutina } 2009\end{array}$ & $32.0 \pm 12.1$ & $5.8 \pm 1.6$ & $\mathrm{C}$ \\
\hline $\begin{array}{l}\text { Aponema minutissima Kovalyev } \\
\text { et Miljutina } 2009\end{array}$ & $13.1 \pm 6.0$ & $2.4 \pm 1.1$ & $\mathrm{C}$ \\
\hline $\begin{array}{l}\text { Cervonema proximamphidium } \\
\text { Tchesunov } 2000\end{array}$ & $0.7 \pm 0.4$ & $0.3 \pm 0.2$ & $\mathrm{D}$ \\
\hline $\begin{array}{l}\text { Daptonema modestum } \\
\text { Tchesunov 1990c }\end{array}$ & $3.5 \pm 2.1$ & $0.5 \pm 0.2$ & $\mathrm{~B}$ \\
\hline $\begin{array}{l}\text { Desmoscolex paragranulatus } \\
\text { Decraemer et Tchesunov } 1996\end{array}$ & $1.1 \pm 0.8$ & $0.2 \pm 0.1$ & $\mathrm{~B}$ \\
\hline $\begin{array}{l}\text { Desmoscolex petaloides } \\
\text { Lorenzen } 1972\end{array}$ & $1.0 \pm 0.4$ & $0.3 \pm 0.1$ & $\mathrm{~B}$ \\
\hline $\begin{array}{l}\text { Diplopeltula incisa Southern } \\
1914\end{array}$ & $1.2 \pm 0.5$ & $0.5 \pm 0.2$ & $\mathrm{~B}$ \\
\hline Filipjeva arctica Ditlevsen 1928 & $2.2 \pm 1.0$ & $1.1 \pm 0.7$ & A \\
\hline $\begin{array}{l}\text { Filipjeva filipjevi Tchesunov } \\
\text { 1988a }\end{array}$ & $23.7 \pm 5.7$ & $8.1 \pm 1.5$ & $\mathrm{~B}$ \\
\hline $\begin{array}{l}\text { Fusivermis fertilis Tchesunov } \\
\quad 1996\end{array}$ & $4.4 \pm 2.7$ & $0.8 \pm 0.3$ & $\mathrm{~B}$ \\
\hline $\begin{array}{l}\text { Geomonhystera disjuncta } \\
\text { (Bastian 1865) Jacobs } 1987\end{array}$ & $1.2 \pm 0.6$ & $0.4 \pm 0.3$ & $\mathrm{~B}$ \\
\hline $\begin{array}{l}\text { Gerlachius lissus (Gerlach 1956) } \\
\text { Andrássy } 1976\end{array}$ & $0.1 \pm 0.1$ & $0.0 \pm 0.0$ & A \\
\hline $\begin{array}{l}\text { Intasia monchystera Tchesunov } \\
\text { et Miljutina } 2008\end{array}$ & $2.8 \pm 0.9$ & $0.8 \pm 0.3$ & $\mathrm{C}$ \\
\hline $\begin{array}{l}\text { Marisalbinema galtsovae } \\
\text { Tchesunov 1990c }\end{array}$ & $1.2 \pm 1.0$ & $0.5 \pm 0.5$ & $\mathrm{D}$ \\
\hline $\begin{array}{l}\text { Pselionema simplex De Coninck } \\
1942\end{array}$ & $3.6 \pm 1.2$ & $0.8 \pm 0.2$ & $\mathrm{~B}$ \\
\hline Sabatieria ornata Ditlevsen 1918 & $41.2 \pm 6.4$ & $17.3 \pm 2.5$ & A \\
\hline $\begin{array}{l}\text { Thalassomonhystera } \\
\text { bathyslandica Riemann } 1995\end{array}$ & $0.1 \pm 0.1$ & $0.0 \pm 0.0$ & $\mathrm{E}$ \\
\hline
\end{tabular}

A: wide-spread in the North Atlantic (including shallow waters), not previously reported from Kandalaksha Bay; B: known from shallow-water North Atlantic sites and the tidal and/or upper subtidal zone of Kandalaksha Bay; C: described during this study; D: described from the lower subtidal zone of Kandalaksha Bay (depth ca. $70 \mathrm{~m}$ ) and not recorded elsewhere; and E: previously only known from the deep Atlantic

During the examination of nematode specimens, the life stage (juvenile or adult) and gender (for adult specimens) were recorded. Patterns in the proportions of juveniles, males, and females were studied separately for the three most abundant species, Filipjeva filipjevi (211 individuals in total), Aponema bathyalis (234 individuals), and Sabatieria ornata (619 individuals), and pooled for all other species (2,149 individuals). 


\section{Results}

Nematode assemblage composition

In total, 59 nematode morphotypes were distinguished, which could be allocated to 37 genera from 18 families. The most species-rich families were Xyalidae and Diplopeltidae (ten species in each), followed by Desmoscolecidae and Chromadoridae (six and five species, respectively).
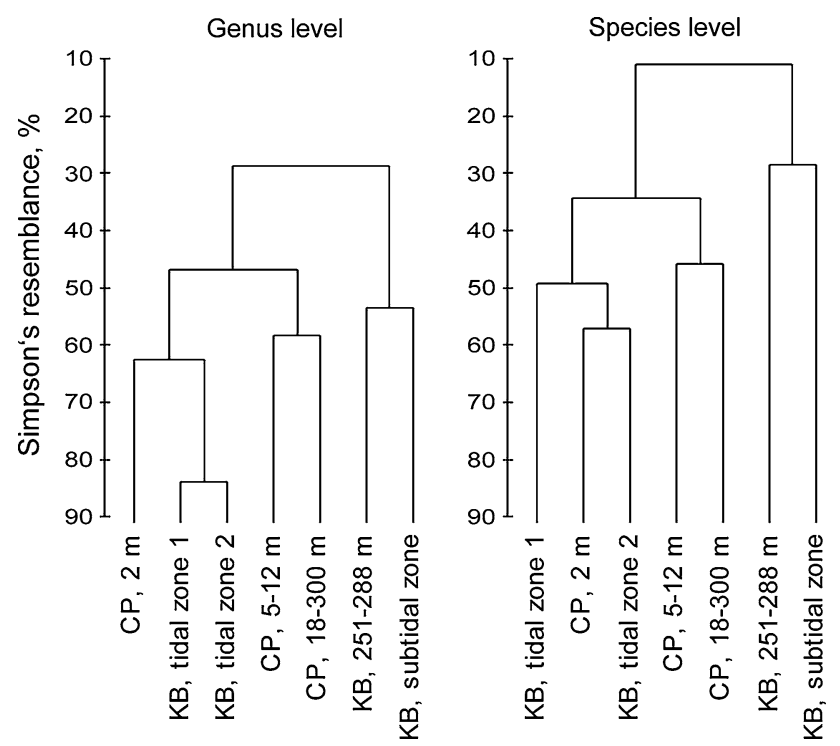

Fig. 2 Cluster analysis ordination to compare nematode assemblage presence/absence data from the current study with that from other White Sea sites. Based on average Simpson's resemblance index. Abbreviations: $C P$ Central pWhite Sea, $K B$ Kandalakscha Bay. Sources: KB 251-288 m (present data); KB tidal zone 1 and $\mathrm{KB}$ subtidal zone (Tchesunov and Walter, 2008); CP $2 \mathrm{~m}, \mathrm{CP} 5-12 \mathrm{~m}, \mathrm{CP}$ 18-300 $\mathrm{m}$, and KB tidal zone 2 (Galtsova 1991). For more detail on the literature sources, see Table 4
About $55 \%$ of genera were represented by only one species, and $34 \%$ of genera had 2 species. The most speciesrich genera (each containing three species) were Desmoscolex, Campylaimus, and Filipjeva (Table 2). The average number of species per genus and per family was 1.6 and 3.2 , respectively.

Nineteen morphotypes were identified as known species (Table 3). Of these, three were described from the present samples (Aponema bathyalis, A. minutissima, and Intasia monhystera) (Tchesunov and Miljutina 2008; Kovalyev and Miljutina 2009). Three valid species (Sabatieria ornata, Filipjeva filipjevi, and A. bathyalis) were the most abundant in the nematode assemblages described here. Four valid species (Aegialoalaimus elegans, Filipjeva arctica, Gerlachius lissus, and S. ornata) were described from the White Sea for the first time (Habitat "A"). About one half (nine) of the valid species were previously known from the tidal and/or subtidal zone of the Kandalaksha Bay.

According to the analysis of Simpson's resemblance (based on a presence/absence matrix of found valid species and genera), the nematofauna from the Kandalaksha Depression was most similar to the subtidal nematode fauna from the Kandalaksha Bay in the area of the White Sea Biological Station (Fig. 2, Table 4). This resemblance is not strong (ca. $28 \%$ at species level, ca. $53 \%$ at genus level); however, its similarity to other nematofaunas from the White Sea was even less (Fig. 2).

The nematofauna from the Kandalaksha Depression did not resemble the other deep-sea (18-300 m) nematofauna (Galtsova 1991); it was only $4 \%$ similar at species level and $33 \%$ at genus level. The relative abundances of genera differed markedly too (Table 5). The genera Metadesmolaimus and Aegialoalaimus were most abundant in the Galtsova's study, whereas these genera were not numerous or not found at all in the present study. In contrast, the

Table 4 Site information and number of valid nematode taxa recorded at different locations in the White Sea used for resemblance analysis (Simpson's resemblance index)

\begin{tabular}{|c|c|c|c|c|c|}
\hline \multirow[t]{2}{*}{ Area } & \multirow[t]{2}{*}{ Site } & \multirow[t]{2}{*}{ Sampling depth } & \multicolumn{2}{|c|}{$\begin{array}{l}\text { Number of valid } \\
\text { taxa recorded }\end{array}$} & \multirow[t]{2}{*}{ Source } \\
\hline & & & Species & Genera & \\
\hline Kandalaksha Bay & Kandalaksha depression & $251-288 \mathrm{~m}$ & 23 & 40 & Present work \\
\hline Central part of the White Sea & n.a. & $18-300 \mathrm{~m}$ & 24 & 23 & Galtsova (1991) \\
\hline Kandalaksha Bay & n.a. & $5-12 \mathrm{~m}$ & 31 & 29 & Galtsova (1991) \\
\hline Kandalaksha Bay & n.a. & $2 \mathrm{~m}$ & 28 & 23 & Galtsova (1991) \\
\hline Kandalaksha Bay & n.a. & Tidal zone, sand beaches & 35 & 25 & Galtsova (1991) \\
\hline Kandalaksha Bay & $\begin{array}{l}\text { White Sea Biological Station } \\
\left(\approx 66^{\circ} 33^{\prime} \mathrm{N}, 33^{\circ} 7^{\prime} \mathrm{E}\right)\end{array}$ & Tidal zone & 59 & 49 & Tchesunov and Walter (2008) \\
\hline Kandalaksha Bay & White Sea Biological Station & Subtidal zone, ca. 0-20 m & 74 & 53 & Tchesunov and Walter (2008) \\
\hline
\end{tabular}

n.a. not available 
Table 5 Proportions (averaged over all full cores) of the 10 most abundant genera and their contribution to dissimilarities (\%, result of SIMPER test) between the relative abundance of nematode genera from the present study and from a similar depth range in the White Sea Basin (data from Galtsova 1991)

\begin{tabular}{|c|c|c|c|}
\hline \multirow[t]{2}{*}{ Genus } & \multicolumn{2}{|c|}{ Average abundance $(\%)$} & \multirow{2}{*}{$\begin{array}{l}\text { Contribution } \\
\text { to } \\
\text { dissimilarity } \\
\text { (\%) }\end{array}$} \\
\hline & $\begin{array}{l}\text { Galtsova } \\
\text { (1991), depth } \\
18-300 \mathrm{~m}\end{array}$ & $\begin{array}{l}\text { Present study, } \\
\text { depth } \\
251-288 \mathrm{~m}\end{array}$ & \\
\hline Metadesmolaimus & 12.9 & 0 & 8.8 \\
\hline Sabatieria & 6.5 & 18.2 & 8.4 \\
\hline Filipjeva & 0 & 10.3 & 7.0 \\
\hline Aegialoalaimus & 10.5 & 0.8 & 6.6 \\
\hline Mesacanthion & 7.1 & 0 & 4.8 \\
\hline Thoracostomopsis & 7.0 & 0 & 4.8 \\
\hline Aponema & 0 & 5.8 & 4.0 \\
\hline Oxystomina & 5.6 & 0.3 & 3.6 \\
\hline Terschellingia & 5.3 & 0 & 3.6 \\
\hline Desmoscolex & 0 & 5.0 & 3.4 \\
\hline
\end{tabular}

genera Sabatieria and Filipjeva dominated in the present study, but were much less abundant or not mentioned in the Galtsova's study.

The three most abundant species, S. ornata, A. bathyalis, and F. filipjevi, comprised 19.2, 7.3, and $6.6 \%$ of total nematode abundance, respectively. The maximum density of these species was recorded in October 1998 (176.6 ind./ $10 \mathrm{~cm}^{2}, 85.0$ ind. $/ 10 \mathrm{~cm}^{2}$, and 72.6 ind. $/ 10 \mathrm{~cm}^{2}$, respectively) (Table 6).

At genus level, Sabatieria and Filipjeva were dominant at all stations, followed by Aponema, Desmoscolex, and Quadricoma. The families Comesomatidae and Xyalidae dominated at three of the four stations, while Xyalidae and Desmoscolecidae dominated at CBB-34 with Comesomatidae being the third most abundant family (Table 6).

A two-way nested ANOSIM test showed significant differences in relative abundance of nematode species between stations $(p=0.02)$, but there was no difference between deployments $(p=0.22)$. The differences between assemblages at the stations mainly reflected differences in the proportions of the most abundant species (A. bathyalis, S. ornata, F. filipjevi, Desmoscolex sp.).

The Kruskal-Wallis tests indicated no significant differences in diversity indices between different stations for the top $0-5 \mathrm{~cm}$ of the sediment ( $p$ values in all pairwise comparisons were $>0.05$ ), and therefore, the values were averaged across stations. The diversity indices are given in the Table 7.

Proportions of life stages and genders

The proportion of juveniles in the top $0-5 \mathrm{~cm}$ of the sediment varied from 36 to $88 \%$ for all species (average
$52.8 \%$ ), with no dependence on season or year of sampling detected (Table 8).

The proportions of life stages and genders were examined separately for the three most abundant species $(F$. filipjevi, A. bathyalis, and $S$. ornata) and pooled for all other species (Fig. 3). On average, F. filipjevi was represented by $55.2 \pm 4.5 \%$ juveniles, while A. bathyalis, $S$. ornata, and the remaining pooled species were $63.8 \pm 10.9 \%, 77.2 \pm 2.8 \%$, and $45.7 \pm 1.9 \%$ juveniles, respectively. There was a significantly greater proportion of juvenile $S$. ornata than for both $F$. filipjevi and the remaining pooled species (Mann-Whitney $U$ test: $p=0.03$ for both pairwise comparisons).

The average ratio of males/females in F. filipjevi, A. bathyalis, $S$. ornata, and the remaining pooled species was $1.88 \pm 0.09,2.39 \pm 0.14,0.84 \pm 0.04$, and $0.57 \pm 0.01$, respectively. Thus, it was significantly greater than 1 in $F$. filipjevi and A. bathyalis ( $\chi^{2}$ test: $p<0.01$ for both species) and significantly less than 1 for the pooled species $\left(\chi^{2}\right.$ test: $p<0.01)$. There was no significant difference in the proportion of males and females in $S$. ornata $\left(\chi^{2}\right.$ test: $p=0.23$ ).

\section{Vertical distribution}

The one-way ANOSIM test separately preformed for "Station," "Deployment," and "Sediment layer" factors indicated no significant influence of the "Deployment" factor $(p=0.07)$ on the composition of nematode assemblages at species level, but the factors "Station" and "Sediment layer" were significant $(p<0.03$ and 0.01 , respectively). Of the most abundant species, $S$. ornata and F. filipjevi normally dominated the $1-2-\mathrm{cm}$ and $2-3-\mathrm{cm}$ sediment layers. All stations were dominated by the same species complex, but their ranks varied (Table 9).

The similarity within samples from different sediment layers increased with increasing sediment depth: average similarity within samples from $0-1-\mathrm{cm}, 1-2-\mathrm{cm}$, and 2-3$\mathrm{cm}$ sediment layers was 29,41 , and $53 \%$, respectively (results of one-way SIMPER analysis for the factor "Sediment layer").

The evenness of nematode assemblages decreased with increasing sediment depth (Table 10), as did other diversity indices. Kruskal-Wallis tests indicated no significant differences in diversity indices between nematode species assemblages from the $0-1-\mathrm{cm}$ and the $1-2-\mathrm{cm}$ sediment layers, but there were significant differences between these layers and the $2-3-\mathrm{cm}$ sediment layer. Diversity indices were significantly lower in the $2-3-\mathrm{cm}$ sediment layer (Table 11).

There was also a significant difference (Kruskal-Wallis test: $p<0.04)$ in proportions of juveniles between the $0-1$ $\mathrm{cm}$ and $2-3-\mathrm{cm}$ sediment layers (50.4 and $61.2 \%$, 


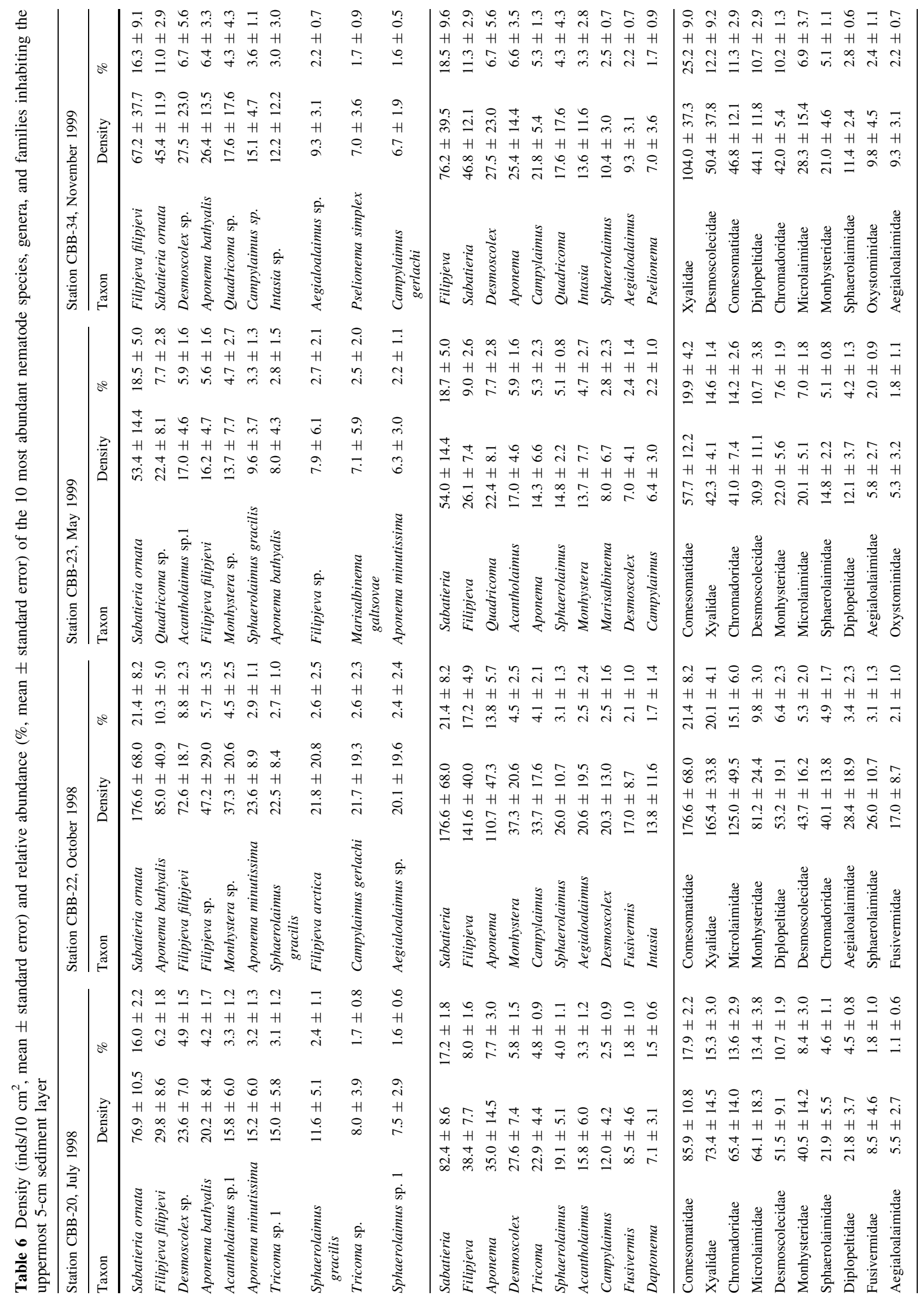


respectively). The proportion of juveniles in 1-2-cm sediment layer was intermediate $(56.6 \%)$ and did not differ significantly from the upper or lower layer.

\section{Discussion}

Assemblage composition and structure

A significant difference in the composition of nematode assemblages between different stations (sampling occasions) was reported. However, the sampling strategy did not allow replication of stations over time (stations differed from each other not only in date of sampling, but also in their geographical position and depth), and this created difficulties in the interpretation of results, since apparent differences between sampling occasions could be affected not only by the time period but also by spatial parameters. Nevertheless, it was previously shown that a significant

Table 7 Diversity indices (mean \pm standard error) for the nematode assemblage from the deepest part of the Kandalaksha Depression at species and genus level

\begin{tabular}{lcc}
\hline Diversity index & Species level & Genus level \\
\hline$d$ & $4.65 \pm 0.24$ & $3.46 \pm 0.14$ \\
$J^{\prime}$ & $0.788 \pm 0.018$ & $0.784 \pm 0.022$ \\
$H^{\prime}\left(\log _{2}\right)$ & $3.54 \pm 0.07$ & $3.18 \pm 0.08$ \\
$H^{\prime}\left(\log _{\mathrm{e}}\right)$ & $2.43 \pm 0.05$ & $2.20 \pm 0.05$ \\
$N_{\infty}$ & $3.80 \pm 0.31$ & $3.50 \pm 0.26$ \\
$E(51)$ & $16.1 \pm 0.4$ & $13.1 \pm 0.4$ \\
$E(100)$ & $21.9 \pm 0.9$ & $17.5 \pm 0.6$ \\
\hline
\end{tabular}

Data averaged over the upper $5-\mathrm{cm}$ sediment layer part of the variance in total meiobenthos density in these samples was explained by seasonality (Miljutin et al. 2012). Yet, other studies have found no significant seasonal variation in the composition of marine nematode assemblages under stable environmental conditions (Warwick and Buchanan 1971; Pavlyuk 2000). Temperature seems to be very stable in the Kandalaksha Depression, but significant seasonal variation in sedimentation from primary production has been recorded (Miljutin et al. 2012). This variability in sedimentation rates may induce seasonal mass propagation of particular species, resulting in changes to the composition of deep-sea benthic communities (Gooday 2002).

The genera Sabatieria and Filipjeva were the most abundant at all stations. Sabatieria has been characterized as the most common dominant genus on the shelf break (Soetaert et al. 1995). Often it has been recorded as one of the most abundant genera from the lower shelf to the medium slope and in canyons in the temperate and Arctic waters (Tietjen 1976; Vanreusel et al. 1992; Soetaert and Heip 1995; Soetaert et al. 1995; Vanaverbeke et al. 1997b; De Leonardis et al. 2008). Sabatieria was not found to be abundant over the same depth range in the Arctic Laptev Sea, however (Vanaverbeke et al. 1997a). Similar to slope and other shelf studies (Soltwedel et al. 2009; Vanreusel et al. 2010), the genus Desmoscolex was abundant at some stations. This is the first time, however, that the genera Filipjeva and Aponema have been noted as dominant or subdominant. Thus, the composition of the dominant nematode genera in the deepest part of the White Sea can be considered typical for this depth range in temperate and Arctic waters, but with a new record of dominance for the genera Filipjeva and Aponema.

Table 8 Two-way ANOVA for the factors sampling season ("summer" vs. "autumn") and sampling year (1998 vs. 1999) effects on the ratio "adults/juveniles" across the whole dataset and for the three most abundant species separately

\begin{tabular}{|c|c|c|c|c|c|c|c|}
\hline \multirow[t]{2}{*}{ Species } & \multirow{2}{*}{$\begin{array}{l}\text { Jarque-Bera test for normality ( } \mathrm{p} \text {, Monte-Carlo } \\
\text { method) }\end{array}$} & \multirow{2}{*}{$\begin{array}{l}\text { Two-way ANOVA } \\
\text { parameters }\end{array}$} & \multicolumn{5}{|l|}{ Factors } \\
\hline & & & Season & Year & Interaction & Within & Tota \\
\hline \multirow[t]{3}{*}{ All species } & \multirow[t]{3}{*}{0.103} & $d f$ & 1 & 1 & 1 & 22 & 25 \\
\hline & & $F$ & 0.01842 & 1.505 & 0.08655 & & \\
\hline & & $p$ & 0.89 & 0.23 & 0.77 & & \\
\hline \multirow{3}{*}{$\begin{array}{l}\text { Filipjeva } \\
\text { filipjevi }\end{array}$} & \multirow[t]{3}{*}{0.402} & $d f$ & 1 & 1 & 1 & 10 & 13 \\
\hline & & $F$ & 0.1662 & 0.6174 & 1.099 & & \\
\hline & & $p$ & 0.69 & 0.45 & 0.32 & & \\
\hline \multirow{3}{*}{$\begin{array}{r}\text { Aponema } \\
\text { batyalis }\end{array}$} & \multirow[t]{3}{*}{0.064} & $d f$ & 1 & 1 & 1 & 8 & 11 \\
\hline & & $F$ & 0.06013 & 0.4933 & 2.791 & & \\
\hline & & $p$ & 0.81 & 0.50 & 0.13 & & \\
\hline \multirow{3}{*}{$\begin{array}{c}\text { Sabatieria } \\
\text { ornata }\end{array}$} & \multirow[t]{3}{*}{0.744} & $d f$ & 1 & 1 & 1 & 17 & 20 \\
\hline & & $F$ & 0.7951 & 0.6233 & 0.252 & & \\
\hline & & $p$ & 0.39 & 0.44 & 0.62 & & \\
\hline
\end{tabular}

All data log-normalized 

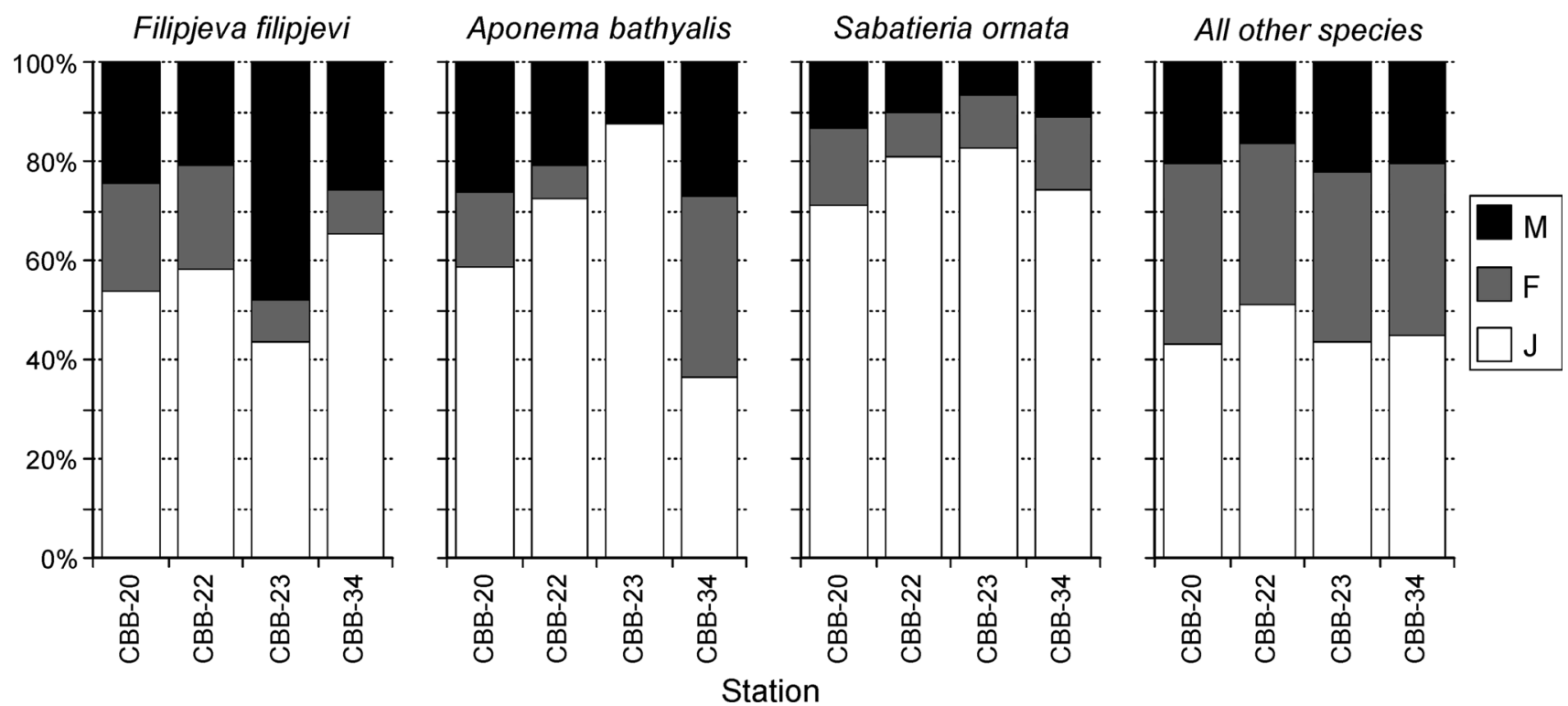

Fig. 3 Proportions $(\%)$ of life stages and genders of nematode assemblages inhabiting the deep White Sea. Each of four cruises shown separately. Abbreviations used in the legend: $J$ juveniles, $F$ females, and $M$ males

Table 9 Relative abundance (\%) of the 5 most dominant nematode species at each station, abundances shown for each sediment layer $(0-1,1-2$, and $2-3 \mathrm{~cm})$

\begin{tabular}{llrrr}
\hline Station & Species & \multicolumn{3}{l}{ Sediment layer } \\
\cline { 3 - 5 } & & $0-1 \mathrm{~cm}$ & $1-2 \mathrm{~cm}$ & $2-3 \mathrm{~cm}$ \\
\hline \multirow{2}{*}{ CBB-20 } & Sabatieria ornata & 2.5 & 25.6 & 52.0 \\
& Filipjeva filipjevi & 1.9 & 12.0 & 17.4 \\
& Desmoscolex sp. & 6.2 & 6.6 & 1.7 \\
& Sphaerolaimus gracilis & 0.7 & 5.4 & 4.2 \\
& Aponema bathyalis & 7.5 & 2.0 & 0.0 \\
CBB-22 & Aponema bathyalis & 4.9 & 28.3 & 8.7 \\
& Filipjeva filipjevi & 4.8 & 1.8 & 21.4 \\
& Sabatieria ornata & 5.1 & 5.8 & 13.6 \\
& Desmoscolex sp. & 9.9 & 8.5 & 1.9 \\
& Monhystera sp. & 12.9 & 7.5 & 0.0 \\
CBB-23 & Sabatieria ornata & 4.3 & 20.9 & 53.6 \\
& Quadricoma sp. & 14.1 & 10.2 & 0.0 \\
& Filipjeva filipjevi & 0.6 & 12.3 & 10.7 \\
& Sphaerolaimus gracilis & 1.4 & 2.6 & 14.3 \\
& Acantholaimus intermedius & 10.4 & 6.7 & 0.0 \\
Filipjeva filipjevi & 6.7 & 9.3 & 43.4 \\
& Sabatieria ornata & 3.3 & 5.8 & 26.4 \\
Desmoscolex sp. & 3.3 & 14.0 & 0.0 \\
& Aponema bathyalis & 3.3 & 11.0 & 1.9 \\
& Campylaimus conicauda & 3.3 & 4.1 & 3.8 \\
\hline
\end{tabular}

The studied nematode assemblage showed the highest resemblance (presence/absence of found valid species and genera) with the assemblage from the subtidal zone in the area of the White Sea Biological Station (WSBS) in the
Table 10 Diversity indices for the nematode species assemblages by sediment layer $(0-1,1-2$, and $2-3 \mathrm{~cm})$

\begin{tabular}{lccc}
\hline Diversity index & \multicolumn{3}{l}{ Sediment layer } \\
\cline { 2 - 4 } & $0-1 \mathrm{~cm}$ & $1-2 \mathrm{~cm}$ & $2-3 \mathrm{~cm}$ \\
\hline$d$ & $4.25 \pm 0.38$ & $4.32 \pm 0.6$ & $2.54 \pm 0.39$ \\
$J$ & $0.850 \pm 0.025$ & $0.800 \pm 0.033$ & $0.730 \pm 0.040$ \\
$E S(31)$ & $13.6 \pm 1.2$ & $13.0 \pm 1.2$ & $8.8 \pm 1.2$ \\
$H^{\prime}$ & $3.59 \pm 0.20$ & $3.46 \pm 0.19$ & $2.47 \pm 0.30$ \\
\hline
\end{tabular}

Table 11 Pairwise comparison of diversity indices of the nematode species assemblages in each sediment layer $(0-1,1-2$, and $2-3 \mathrm{~cm})$

\begin{tabular}{llll}
\hline Diversity & \multicolumn{3}{l}{ Pairwise comparison of sediment layers } \\
\cline { 2 - 4 } indices & $\begin{array}{l}0-1 \text { versus } \\
1-2 \mathrm{~cm}\end{array}$ & $\begin{array}{l}0-1 \text { versus } \\
2-3 \mathrm{~cm}\end{array}$ & $\begin{array}{l}1-2 \text { versus } \\
2-3 \mathrm{~cm}\end{array}$ \\
\hline$d$ & 0.830 & $0.043^{*}$ & $0.011^{*}$ \\
$J^{\prime}$ & 0.284 & $0.043^{*}$ & 0.219 \\
$E S(31)$ & 0.721 & $0.043^{*}$ & $0.047^{*}$ \\
$H^{\prime}$ & 0.830 & $0.043^{*}$ & $0.030^{*}$ \\
\hline
\end{tabular}

Significance levels are results of Kruskal-Wallis tests

* Difference is statistically significant at $p<0.05$

Kandalaksha Bay. A possible reason for this is that the area of the WSBS is the most studied area of the White Sea, resulting in the longest list of nematode taxa in comparison with other studied areas of the White Sea (Table 4). It should be remembered, however, that only 19 of the 59 distinguished morphotypes were attributed to known species, and this may indicate that many species in the studied 
area do not also occur in the shallow waters of Kandalaksha Bay.

The relative abundance of genera differed markedly from that recorded for a comparable depth range in the White Sea Basin, $200 \mathrm{~km}$ from our sampling site (Galtsova 1991). It is difficult to give an unambiguous explanation of this discrepancy. Firstly, it might be explained by possible differences in environmental conditions in these two areas (they are about $200 \mathrm{~km}$ apart). The difference in depth ranges (251-288 $\mathrm{m}$ in the present study vs. $18-300 \mathrm{~m}$ in the Galtsova's study) could also cause the difference between the nematode assemblage compositions. Unfortunately, having described the nematode assemblage from the $18-300 \mathrm{~m}$ material, Galtsova (1991) did not state which specimens were taken from which depth, only that the nematode assemblages were homogenous across this depth range. Alternatively, it might simply reflect a different methodology-Galtsova (1991) used a 90- $\mu \mathrm{m}$ mesh sieve, while a 32- $\mu \mathrm{m}$ sieve was used in the present study. It was shown that about $40 \%$ of nematodes from the Kandalaksha Depression passed through a 125- $\mu \mathrm{m}$ mesh (Miljutin et al. 2012), and consequently, it is possible that Galtsova (1991) lost a considerable number of smaller specimens and species, thereby influencing the nematode assemblage composition recorded.

\section{Diversity}

According to the literature data on diversity of nematode assemblages (at species level) from the northern temperate and Arctic continental shelf, slope, and abyss, $J^{\prime}$ varied from 0.93 to 0.96 in the samples from the Bay of Biscay (Dinet and Vivier 1979); from 0.85 to 0.95 in the Norwegian Sea (Jensen 1988), and from 0.88 to 0.95 at the NE Atlantic slope (Danovaro et al. 2009). The mean $J^{\prime}$ values were 0.85-0.89 for the temperate subtidal zone and the slope (Boucher and Lambshead 1995), 0.83 for the Arctic abyss (Gallucci et al. 2008), and 0.87 for the Haterras Abyssal Plain (Tietjen 1989). In the present study, $J^{\prime}$ was lower (mean, 0.79). Also, in the literature $H^{\prime}\left(\log _{2}\right)$ was 5.23-6.67 (Dinet and Vivier 1979), 4.1 (Tietjen 1989), and 3.79-5.01 (Jensen 1988), and its mean values were 4.88-5.00 (Boucher and Lambshead 1995). Again, this index value was lower in the present study (3.54). Gallucci et al. (2008) reported the mean value of $H^{\prime}\left(\log _{\mathrm{e}}\right)$; this was 3.5 and was also higher than in the present study (2.43). Finally, Boucher and Lambshead (1995) and Lambshead et al. (2000) reported mean values of $E S(51)$ from 24 to 31, while for the Arctic deep seas at the 2,000-m isobath Fonseca and Soltwedel (2009) reported ES(50) varied from 27 to 38 and Danovaro et al. (2009) reported $E S(100)$ from 48 to 65 . The $E S(51)$ and $E S(100)$ indices produced significantly lower values in the present study (16.1 and 21.9, respectively).
At genus level, the diversity indices were also lower compared to previous studies. Vanaverbeke et al. (1997a, b) indicated $N \infty$ values of 5-10 for nematode assemblages from the NE Atlantic and the Laptev Sea (vs. 3.5 on average for the present study). On the Arctic Yemark Plateau, Soltwedel et al. (2009) reported values of $H^{\prime}\left(\log _{2}\right)$ and $\mathrm{J}^{\prime}$ were $4.2-4.6$ and $0.80-0.89$, respectively (vs. 3.2 and 0.784 , respectively, on average in the present study): $H^{\prime}\left(\log _{\mathrm{e}}\right)$ averaged 3.0 in the Arctic abyss (Guilini et al. 2011 ) versus 2.2 in the present study. Finally, EG(100) was 31-39 (Vanaverbeke et al. 1997b) and $24-32$ (Soltwedel et al. 2009) in comparison with a mean value of 17.5 in the present study.

There were several exceptions to the above pattern, where the diversity of the nematode assemblages was comparable with the present data. These were the studies (performed at genus level) by Renaud et al. (2006) on nematode assemblages from the Arctic abyss and by Sebastian et al. (2007) on abyssal nematode assemblages from the Cape Verde Abyssal Plain and the Porcupine Abyssal Plain. In the first study, the $\mathrm{J}^{\prime}$ was $0.64-0.75$, and $H^{\prime}\left(\log _{\mathrm{e}}\right)$ was $2.08-2.45$, compared to mean values of 0.78 and 2.20 , respectively, for the present data. In the latter study, the $N \infty$ values were 3.0-4.2 compared to 3.5 for the present study, but the $H^{\prime}\left(\log _{\mathrm{e}}\right)$ was nevertheless higher (2.4-2.6). Thus, the nematode assemblage of the deepest part of the White Sea appeared to be reduced in diversity in comparison with most studied temperate and Arctic regions.

The diversity indices for nematode assemblages in the different sediment layers decreased with increasing sediment depth: nematode assemblages inhabiting the $2-3-\mathrm{cm}$ sediment layer exhibited stronger dominance and significantly lower species diversity than in the $0-1-\mathrm{cm}$ and 1-2$\mathrm{cm}$ layers. Decreasing nematode diversity with sediment depth was previously shown by Fonseca et al. (2010) in more detail. Generally, the dominance of $S$. ornata and $F$. filipjevi was higher in the deeper sediment layers.

The examined samples were taken in different seasons during different years, and it is possible that the composition of the nematode assemblage was impacted by environmental factors that varied seasonally and/or annually. However, it has been shown that the major taxon composition of the meiobenthos in the deep White Sea does not change with time and only varies with sediment depth (Miljutin et al. 2012). Unfortunately, it was impossible to test this hypothesis here at the species level because nematodes were examined from a relatively small number of samples.

\section{Life history traits}

The proportion of juveniles was maximal in the 1-2-cm sediment layer. It has been already shown that density of 
juveniles also was the highest in the $1-2-\mathrm{cm}$ sediment layer, while adult densities were similar in the $0-1-\mathrm{cm}$ and 1-2-cm layers (Miljutin et al. 2012). Possibly, juveniles prefer inhabiting this subsurface sediment layer.

The proportion of juvenile $S$. ornata was significantly higher than for many other species. Indeed, the proportion of juveniles for the three most abundant species were higher than for other less abundant species. However, the size of nematode species or the age of juveniles could also influence the resulting proportion of juveniles in samples, with smaller larvae being lost to a greater extent than larger ones during sample processing.

Acknowledgments The authors express their gratitude to Prof. Dr. Andrej Azovsky (Moscow State University, Russia) for his valuable help during the execution of this work. The authors also thank Dr. Natalie Barnes (The Natural History Museum, London, UK) for her critical revision and proofreading of the English manuscript and two anonymous reviewers for their invaluable remarks. This study was supported by the International Association for the Promotion of Cooperation with Scientists from the New Independent States of the Former Soviet Union (INTAS, Grant No. 96-1359) and by the Russian Foundation for Basic Research (Grant Nos. 12-04-00781, 08-0500201, and 06-04-48633).

\section{References}

Aminova DG, Galtzova VV (1978) New species of free-living marine nematodes from the White Sea. Zoologicheskii Zhurnal 57(11):1727-1729 (In Russian)

Andrássy I (1976) Evolution as a basis for the systematization of nematodes. Petman Publication, London

Andriashev AP (1977) Some additions to schemes of the vertical zonation of marine bottom fauna. In: Llano GA (ed) Adaptations within Antarctic ecosystems. Gulf Publishing Company, Houston, pp 351-360

Bastian H (1865) Monograph on the Anguillulidae, or free Nematoids, marine, land, and freshwater; with descriptions of 100 new species. Trans Linn Soc Lond 25:73-184

Belogurov OI, Galtzova VV (1983) On taxonomic status of some Oncholaimidae (Nematoda) from the White Sea, previously described as new species. Zoologicheskij Zhurnal 62(9):1314-1320 (In Russian)

Berger VY, Naumov AD (2000) General features of the White Sea. Morphology, sediments, hydrology, oxygen conditions, nutrients and organic matter. In: Rachor E (ed) Scientific cooperation in the Russian Arctic: ecology of the White Sea with emphasis on its Deep Basin. Ber Polarforsch 359:3-9

Berger V, Dahle S, Galaktionov K, Kosobokova X, Naumov A, Rat'kova T, Savinov V, Savinova T (2001) White Sea. Ecology and environment. Derzavets Publ S.Petersburg-Troms $\varnothing$

Boucher G, Lambshead PJD (1995) Ecological biodiversity of marine nematodes in samples from temperate, tropical, and deep-sea regions. Conserv Biol 9(6):1594-1604

Clarke KR, Gorley RN (2006) PRIMER v6: user manual/tutorial, PRIMER-E, Plymouth UK

Danovaro R, Bianchelli S, Gambi C, Mea M, Zeppilli D (2009) $\alpha-, \beta-$, $\gamma-, \delta$ - and $\varepsilon$-diversity of deep-sea nematodes in canyons and open slopes of Northeast Atlantic and Mediterranean margins. Mar Ecol Progr Ser 396:197-209
De Coninck LA (1942) Sur quelques espèces nouvelles de Nèmatodes libres (Ceramonematinae Cobb, 1933) avec quelques remarques de systèmatique. Bul Mus R Hist Nat Belg 18(22):1-37

De Leonardis C, Sandulli R, Vanaverbeke J, Vincx M, De Zio S (2008) Meiofauna and nematode diversity in some Mediterranean subtidal areas of the Adriatic and Ionian Sea. Scientia Marina 72(1):5-13

De Man JG (1907) Sur quelques espèces nouvelles ou peu connues de Nèmatodes libres habitant les cótes de la Zèlande. Mem Soc Zool Fr 20:33-90

Decraemer W, Tchesunov AV (1996) Some desmoscolecids from the White Sea (Nematoda, Desmoscolecida). Russ J Nematol 4(2):115-130

Dinet A, Vivier M (1979) Le méiobenthos abyssal du Golfe de Gascogne. II. Les peuplements de nématodes et luer diversité spécifique. Cah Biol Mar 20:109-123

Ditlevsen H (1918) Marine freeliving nematodes from Danish waters. Vidensk Meddr Dansk Naturh Foren 70(7):147-214

Ditlevsen H (1928) Free-living marine nematodes from Greenland waters. Medd Gronland 23:199-250

Fadeeva NP (1984) Morphology of two new species of free-living nematodes Gonionchus latentis sp. nov. and Amphimonhystera galea sp. nov. (Nematoda, Xyalidae) from the Japan Sea). Biol Nauki 7:44-48 (In Russian with English summary)

Filatov NN, Pozdnyakov DV, Johannessen OM, Pettersson LH, Bobylev LP (2005) White Sea: its marine environment and ecosystem dynamics influenced by global change. SpringerPraxis, Chichester, UK

Filipjev IN (1927) Les Nématodes libres des mers septentrionales appartenant à la famille des Enoplidae. Arch Naturgeschichte $91 \mathrm{~A}(6): 1-216$

Fonseca G, Soltwedel T (2009) Regional patterns of nematode assemblages in the Arctic deep seas. Polar Biol 32:1345-1357

Fonseca G, Soltwedel T, Vanreusel A, Lindegarth M (2010) Variation in nematode assemblages over multiple spatial scales and environmental conditions in arctic deep seas. Progr Oceanogr 84(3-4):139-254

Frolov YM (1972) On fauna of free-living nematodes from the sandy littoral of the White Sea. In: Dobrovolskij AA (ed) Integrated studies of oceanic nature 3. Moscow State University Print, pp 347-357 (In Russian)

Gallucci F, Fonseca G, Soltwedel T (2008) Effects of megafauna exclusion on nematode assemblages at a deep-sea site. Deep Sea Res I 55:332-349

Galtsova VV (1976) Free-living nematodes as a component of meiobenthos from the Chupa Guba (the White Sea). In: Ushakov PV (ed) Nematodes and their role in meiobenthos. Studies of marine faunas XVII-XXV. Nauka, Leningrad, pp 165-272 (In Russian)

Galtsova VV (1982) Vertical distribution of meiofauna in sediments from the tidal zone of the White Sea. Biologija Morya 1:52-54 (In Russian)

Galtsova VV (1991). Meiobenthos in marine ecosystems (with special reference to freeliving nematodes). In: Proceedings of the Zoological Institute of USSR Academy of Sciences, 224. Leningrad (In Russian)

Galtsova VV, Aminova DG (1978) Composition and seasonal distribution of meiofauna in the Chupa Guba (the White Sea). Biologija Morya 6:23-32 (In Russian)

Galtsova VV, Platonova TA (1988) The organization and species structure of nematode taxocene of south-eastern part of the Kandalaksha Bay of the White Sea. In: Golikov AN (ed) Benthic ecosystems of the south-eastern part of the Kandalaksha Bay and adjacent waters of the White Sea. Explorations of the fauna of the seas, 38(46). Leningrad, Zoological institute of the USSR Academy of Sciences, pp 75-87 (In Russian) 
Gerlach SA (1956) Diagnosen neuer Nematoden aus der Kieler Bucht. Kieler Meersforsch 12:85-109

Gooday AJ (2002) Biological responses to seasonally varying fluxes of organic matter to the ocean floor: a review. J Oceanogr $58: 305-332$

Guilini K, Soltwedel T, van Oevelen D, Vanreusel A (2011) DeepSea nematodes actively colonise sediments, irrespective of the presence of a pulse of organic matter: results from an in situ experiment. PLoS ONE 6(4):e18912. doi:10.1371/journal.pone. 0018912

Hammer $\varnothing$, Harper DAT, Ryan PD (2001) PAST: paleontological statistics software package for education and data analysis. Palaeontol. Electron. 4. http://www.uv.es/pe/2001_1/past/past. pdf. Accessed 21 May 2013

Jacobs LJ (1987) A redefinition of the genus Monhystrella Cobb (Nematoda, Monhysteridae) with keys to the species. Zool Scr 16(3):191-197

Jensen P (1988) Nematode assemblages in the deep-sea benthos of the Norwegian Sea. Deep Sea Res I 35(7):1173-1184

Kovalyev SV, Miljutina MA (2009) A review of the genus Aponema Jensen, 1978 (Nematoda: Microlaimidae) with description of three new species. Zootaxa 2077:56-68

Kovalyev SV, Tchesunov AV (2005) Taxonomic review of microlaimids with description of five species from the White Sea (Nematoda: Chromadoria). Zoosystematica Rossica 14(1):1-16

Krasnova ED (2007) Life cycle of the free-living marine nematode Metachromadora (Chromadoropsis) vivipara on the littoral of the White Sea. Zoologicheskij Zhurnal 86(5):515-525 (In Russian with English summary)

Lambshead PJD, Tietjen J, Ferrero T, Jensen P (2000) Latitudinal diversity gradients in the deep sea with special reference to North Atlantic nematodes. Mar Ecol Progr Ser 194:159-167

Loeng H (1991) Features of the physical oceanographic conditions of the Barents Sea. In: Sakshaug E, Hopkins CCE, Øritsland NA (eds) Proceedings of the Pro Mare Symposium on Polar Marine Ecology. Trondheim, 12-16 May 1990. Polar Res 10:5-18

Lorenzen S (1972) Desmoscolex-Arten (freilebende Nematoden) von der Nord- und Ostsee. Veröff Inst Meeresforsch Bremenh 13:307-316

Miljutin DM, Miljutina MA, Mokievsky VO, Tchesunov AV (2012) Benthic meiofaunal density and community composition in the deep White Sea and their temporal variations. Polar Biol 35(12): $1837-1850$

Mokievsky VO (1990) The seasonal changes of the intertidal nematode community. In: Kuznetsov AP (ed) Feeding and bioenergetics of marine bottom invertebrates. PP Shirshov Institute of oceanology, Academy of Sciences of the USSR, Moscow, pp 138-149 (In Russian)

Mokievsky VO, Miljutina MA, Tchesunov AV, Rybnikov PV (2009) Meiobenthos of the deep part of the White Sea. Meiofauna Marina 17:61-70

Okhlopkov JR (2002) Free-living nematodes of the families Selachinematidae and Richthersiidae in the White Sea (Nematoda, Chromadoria). Zoosystematika Rossica 11(1):41-55

Pavlyuk ON (2000) Seasonal dynamics of density of mass species and trophic groups of free-living marine nematodes. Biologija Morya 26(6):377-384

Platonova TA, Mokievsky VO (1994) Revision of the marine nematodes of the familly Ironidae (Nematoda: Enpolida). Zoosystematica Rossica 3:5-17

Rachor E (ed) (2000) Scientific cooperation in the Russian Arctic: ecology of the White Sea with emphasis on its Deep Basin. Ber Polarforsch 359

Renaud PE, Ambrose WG Jr, Vanreusel A, Clough LM (2006) Nematode and macrofaunal diversity in central Arctic Ocean benthos. J Exp Mar Biol Ecol 330:297-306
Riemann F (1995) The deep-sea nematode Thalassomonhystera bathyslandica sp. nov. and microhabitats of nematodes in flocculent surface sediments. J Mar Biol Assoc UK 75:715-724

Sebastian S, Raes M, De Mesel I, Vanreusel A (2007) Comparison of the nematode fauna from the Weddell Sea Abyssal Plain with two North Atlantic abyssal sites. Deep Sea Res II 54:1727-1736

Seinhorst JW (1959) A rapid method for the transfer of nematodes from fixative to anhydrous glycerin. Nematologica 4:67-69

Simpson GG (1960) Notes on the measurement of faunal resemblance. Am J Sci Bradley 258-A:300-311

Soetaert K, Heip C (1995) Nematode assemblages of deep-sea and shelf break sites in the North Atlantic and Mediterranean Sea. Mar Ecol Progr Ser 125:171-183

Soetaert K, Vincx M, Heip C (1995) Nematode community structure along a Mediterranean shelf-slope gradient. P.S.Z.N.I. Mar Ecol 16(3):189-206

Soltwedel T, Mokievsky V, Schewe I, Hasemann C (2009) Yermak Plateau revisited: spatial and temporal patterns of meiofaunal assemblages under permanent ice-coverage. Polar Biol 32:1159-1176

Southern R (1914) Nemathelmia, Kinorhyncha and Chaetognatha (Clare Island survey, part 54). Proc R Ir Acad 31:1-80

Tchesunov AV (1987) Free-living nematodes of the genus Sphaerolaimus Bastian, 1865 (Chromadoria, Monhysterida, Sphaerolaimida) from the subtidal zone of the White Sea. Biologicheskije Nauki 5:35-42 (In Russian)

Tchesunov AV (1988a) Free-living marine nematodes of the genus Filipjeva (Monhysterida, Xyalidae). Trudy Zoologicheskogo Instituta 180:16-24 (In Russian with English summary)

Tchesunov AV (1988b) New species nematodes from the White Sea. Trudy Zoologicheskogo Instituta 180:68-76 (In Russian with English summary)

Tchesunov AV (1989) Genus Cyartonema (Nematoda, Chromadorida): morphological peculiarities, new diagnosis, and description of three new species from the White Sea. Zoologicheskij Zhurnal 86(11):5-16 (In Russian with English summary)

Tchesunov AV (1990a) Critical analysis of family Aegialoalaimidae (Nematoda, Chromadoria), trends of evolution of pharynx in free-living nematodes and proposal of two new families. Zoologicheskij Zhurnal 69(8):5-18 (In Russian with English summary)

Tchesunov AV (1990b) Hirsute Xyalidae (Nematoda, Chromadoria, Monhysterida) from the White Sea: new species, new combinations, and status of the genus Trichotheristus. Zoologicheskij Zhurnal 69(10):5-19 (In Russian with English summary)

Tchesunov AV (1990c) New taxa of free-living nematodes of the family Xyalidae Chitwood, 1951 (Nematoda, Chromadoria, Monhysterida) from the White Sea. In: Gagarin VG (ed) Fauna, biology, and systematic of free-living lower worms. Trudy Instituta Bnutrennich Vod SSSR 64-67, Rybinsk, pp 101-117 (In Russian)

Tchesunov AV (1993) Notes on the family Tubolaimoididae Lorenzen, 1981 (Nematoda), with a description of a new species. Russ J Nematol 1(2):121-129

Tchesunov AV (1996) A new nematode family Fusivermidae fam. $n$. (Monhysterida) for Fusivermis fertilis gen. n., sp. n. from the White Sea. Nematologica 42:35-41

Tchesunov AV (2000a) Descriptions of Pseudosteineria horrida (Steiner, 1916) and P. ventropapillata sp. nov. from the White Sea with a review of the genus Pseudosteineria Wieser, 1956 (Nematoda: Monhysterida: Xyalidae). Ann Zool 50(2):281-287

Tchesunov AV (2000b) Several new and known species from the families Coninckiidae and Comesomatidae (Nematoda) in the White Sea. Hydrobiologia 435:43-59

Tchesunov AV, Krasnova ED (1985) On morphology, variability, and synonymy of free-living nematode Chromadoropsis vivipara 
(Chromadoris, Desmodorida, Spiriniidae) from the White Sea. Zoologicheskij Zhurnal 64(3):347-358 (In Russian with English summary)

Tchesunov AV, Miljutina MA (2002) A review of the family Ceramonematidae (marine free-living nematodes), with descriptions of nine species from the White Sea. Zoosystematica Rossica 11(1):3-39

Tchesunov AV, Miljutina MA (2008) A new free-living nematode Intasia monohystera gen. n., sp. n. (Nematoda, Araeolaimida, Diplopeltidae) from the Barents Sea and the White Sea, with a key to genera of Diplopeltidae. Russ J Nematol 16(1):33-48

Tchesunov AV, Milyutin DM (2007) Free-living nematodes of the genus Alaimella Cobb 1920 (Nematoda: Leptolaimidae): a description of A. macramphis sp. n. from the White Sea and a revision of the genus. Russ J Mar Biol 33(2):92-97

Tchesunov AV, Walter ED (2008) Phylum Nematoda Rudolphi 1808, round worms. In: Tchesunov AV, Kalyakina NM, Bubnova EN (eds) A catalogue of biota of the White Sea Biological Station of the Moscow State University. KMK Scientific Press Ltd, Moscow, pp 330-338 (In Russian)

Tchesunov AV, Kalyakina NM, Bubnova EN (eds) (2008) A catalogue of biota of the White Sea Biological Station of the Moscow State University. KMK Scientific Press Ltd (In Russian), Moscow

Tietjen JH (1976) Distribution and species diversity of deep-sea nematodes off North Carolina. Deep Sea Res 23:55-768
Tietjen JH (1989) Ecology of deep-sea nematodes from the Puerto Rico Trench area and Hatteras Abyssal Plain. Deep Sea Res 10:1579-1594

Vanaverbeke J, Arbizu PM, Dahms H-U, Schminke HK (1997a) The metazoan meiobenthos along a depth gradient in the Arctic Laptev Sea with special attention to nematode communities. Polar Biol 18:391-401

Vanaverbeke J, Soetaert K, Heip C, Vanreusel A (1997b) The metazoan meiobenthos along the continental slope of the Goban Spur (NE Atlantic). J Sea Res 38:93-107

Vanreusel A, Vincx M, Van Gansbeke D, Gijselinck W (1992) Structural analysis of the meiobenthos communities of the shelf break area in two stations of the Gulf of Biscay (N.E. Atlantic). Belg J Zool 122:185-202

Vanreusel A, Fonseca G, Danovaro R, da Silva MC, Esteves AM, Ferrero T, Gad G, Galtsova V, Gambi C, Genevois V, Ingels J, Ingole B, Lampadariou N, Merckx B, Miljutin D, Miljutina M, Muthumbi A, Netto S, Portnova D, Radziejewska T, Raes R, Tchesunov A, Vanaverbeke J, Van Gaever S, Venekey V, Bezerra T, Flint H, Copley J, Pape P, Zeppeli D, Martinez Arbizu P, Galeron J (2010) The importance of deep-sea habitat heterogeneity for global nematode diversity. Mar Ecol 31(1):6-20

Warwick RM, Buchanan JB (1971) The meiofauna off the coast of Northumberland II. Seasonal stability of the nematode population. J Mar Biol Assoc UK 51:355-362 